\title{
Population growth
}

\author{
Susannah H. Mayhew ${ }^{*}$ and Tim Colbourn ${ }^{\dagger}$ \\ ${ }^{*}$ London School of Hygiene and Tropical Medicine, Department of \\ Global Health and Development, ${ }^{\top}$ University College London, Institute for \\ Global Health

\section{What is the historical process by which goal setting in this sector has developed?}

Population movement has a long and political history, with goal setting linked at various times to macro-economic and development decisions, women's health, conservative religious agendas, and individual rights.

Since the 1950s, demographics has been seen as a core consideration of economic development. Overpopulation and rapid population growth were seen as major barriers to economic growth (Coale \& Hoover 1958), sometimes linked to more Malthusian concerns about overreaching the Earth's human carrying capacity (Ehrlich 1968; Meadows et al. 1972). This led many developing countries to invest in the procurement and distribution of commercially accessible contraception throughout the 1950s and 60s, in order to secure economic progress. Formal government family planning programmes were established in many developing countries over the next three decades. The development of NGOs also proliferated: the IPPF was founded in 1952 and the UNFPA was founded in 1969. Family planning programmes tended to focus on limiting numbers of births among married women. In some parts of the world (notably India and China) this narrow approach led, in some cases, to coercive practices that tainted the entire population agenda with the spectre of population control, and even eugenics. In India, the forced sterilisation programme of the mid 1970s brought down a Government. In China,

\section{How to cite this book chapter:}

Mayhew, S. H. and Colbourn, T. 2015. Population growth. In: Waage, J and Yap, C. (eds.) Thinking Beyond Sectors for Sustainable Development. Pp. 37-44. London: Ubiquity Press. DOI: http://dx.doi.org/10.5334/bao.e 
the one-child policy and aggressive promotion of long-acting contraceptives initiated in 1978 brought many millions of people out of poverty; however, this was at the expense of abuses of individual rights (especially of women), including forced abortions, sterilisations, and a wide range of severe socio-economic penalties. Population programmes became politically toxic and family planning was relegated to a mere women's health issue.

During the late 1980s and early 1990s, a broad coalition of women's health and rights groups emerged which collectively gained experience in lobbying the United Nations agencies tasked with sexual and reproductive health and rights (SRHR) issues. They were fighting (particularly through the United Nations conference processes) for a move away from equating reproductive issues solely with fertility control, to encompass a more holistic approach to people's SRH needs (Dixon-Mueller 1993; Sen, Germain \& Chen 1994). At the same time the rise of HIV was attracting substantial attention, and its link with a range of other sexually transmitted infections (STIs) led to a broad consensus on the need to tackle such diseases together with reproductive services as part of a more holistic approach. These changes in attitude and approach crystallised at the International Conference on Population and Development (ICPD) in Cairo in 1994. The resulting 20-year Programme of Action was a paradigm shift, embracing a reproductive health agenda built around health, choice, and rights. This approach was reinforced a year later by the Beijing Declaration from the Fourth International Conference on Women in Beijing in 1995, which reaffirmed reproductive rights as basic human rights. In practice, however, the complex and diffuse ICPD agenda was hard to implement, with no clear targets, and resulted in a narrowing of the focus to integration of STI/HIV and family planning/reproductive health services, adolescent SRH, and a general neglect of funding for family planning services. In effect, this progressive agenda was delinked from demographic issues, partly because it was felt important to create an agenda that distanced itself from those policies and programmes which had sometimes been associated with coercive practices (Blanc \& Tsui 2005).

As a result of the ICPD, governments and donors throughout the developing world have pursued a multi-pronged approach to SRHR. This has led to difficulties in prioritisation and resourcing, and has sometimes meant that inappropriate priorities have been pursued to the detriment of family planning investment; for example, a narrow focus on HIV and maternal health targets rather than tackling urgent underlying issues such as adolescent sexuality and health needs and unsafe abortion (Mayhew \& Adjei 2004).

Subsequently, funding for family planning declined significantly, while that for HIV treatment increased exponentially. This was associated with the religiously conservative Bush administration in the US during the 2000s, with its opposition to aspects of contraceptive programmes, abortion, and other SRH and rights issues. As a result, UNFPA took the decision not to hold its 
usual decennial Population Conference, for fear of having the progressive ICPD Programme of Action retracted. In fact, the 1994 ICPD was the last such global conference to take place. Many developing countries saw a slowing and even stalling of the decline in their fertility rates during this period, as well as regression in other health indicators, such as immunisation rates, as population growth increased and public health services struggled to keep up with rapidly increasing populations of children (Bryce et al. 2005). Global population increased from about 5.6 billion in 1994 to more than seven billion in 2015, with the most rapid growth occurring in sub-Saharan Africa. Yet development priorities for health gradually shifted away from population (family planning) towards HIV, while population became incorporated within the broad SRH agenda, rather than being seen as a development issue in its own right.

By the time the MDGs goals and targets were being negotiated, population fell under the remit of the SRH practitioners who had an uneasy relationship with the topic, many wanting to distance themselves from any perceived association with coercion. As a result, they largely failed to see the significance of the MDGs agenda, neglecting to engage in the necessary lobbying to secure SRHR targets within these influential goals. Eventually, after a protracted period of catch-up lobbying, SRHR targets (specifically on achieving universal access to reproductive health, for which various indicators were incorporated) were added and finally accepted in 2008. The lack of demographic or reproductive health goals or targets for so long within the MDGs has led to another de-emphasis of population dynamics on development prospects (Bernstein 2005; Crossette 2005; United Nations Millennium Project 2006).

More recently, however, population issues have been returning to the development discourse within the UK and beyond. More recent reassessments of the impact of demographic trends on economic outcomes have also (re)confirmed that fertility decline (as well as female education and labour force participation) is linked with better economic prospects (Bloom, Canning \& Malaney 2000; Eastwood \& Lipton 1999; Mammen \& Paxson 2000).

In 2006 the UK Government's All Party Parliamentary Group on Population, Development and Reproductive Health held a hearing, resulting in the report Return of the Population Growth Factor (All Parliamentary Group on Population, Development and Reproductive Health 2007). Three years later, the DFID reinstated dedicated funding for research on family planning (alongside abortion), and in 2012 the BMGF held the London Summit on Family Planning, jointly hosted with the DFID, pledging increased funding for family planning and creating the FP2020 global partnership to advance family planning. Concomitant with this, other population dynamics including demographic trends related to urbanisation, migration, ageing, and household composition, as well as population growth, are increasingly being discussed as part of the international development discourse. 


\section{What progress has been achieved in this sector through the Millennium Development Goals and other processes?}

Stabilisation of population growth did not benefit directly or significantly from the MDGs since it was not until 2008 that Target 5B on universal access to SRH, which included measures of contraceptive prevalence rate and unmet need for family planning (i.e. women wishing to stop or delay childbearing but who are not using contraception), was finally adopted. As discussed above, population growth is a very sensitive political issue, and since the 1994 ICPD Programme of Action family planning has suffered declining funding and political commitment, which has affected progress on the fertility indicators.

The global commitment to reducing population growth rates from the $1950 \mathrm{~s}$ contributed to a decline in global total fertility rates (births per woman) for several decades, although in the same time period the world population doubled from three to six billion as a result of population momentum (i.e. the tendency for population growth to continue beyond the time that replacement level fertility has been achieved because of the relatively high concentration of people in their childbearing years). In 2013 the world's population growth rate had slowed from its peak of two per cent per year in the 1960s to 1.1 per cent in 2013, and fertility in Asia and Latin America had dropped from over five births per woman to 2.2. On the whole, those countries and regions where information and contraceptives were made available saw a moderate to rapid decline in the birth rate. In addition, there was an improvement in the economy, the health of women and their families, and the autonomy, education, and status of women. The countries where many pregnancies remained unwanted and the birth rate did not fall are often seeing a growth of urban slums, a failure of the state to keep pace with educational demands and, in some cases, continuing oppression of women.

Since the MDGs were agreed in 2000 the pace of decline has slowed, and in some countries in sub-Saharan Africa it has stalled entirely, even in the few countries like Kenya where fertility decline seemed well established (Bongaarts 2008; Ezeh, Mberu \& Emima 2009). Today in sub-Saharan Africa, the total fertility rate (births per woman) is 5.1 compared to 4.1 across all least developed countries (LDCs), and 2.6 among less developed countries (UNFPA 2013). The official United Nations estimates of global population projections have been creeping upwards over the last decade. Assuming current rates of fertility decline are maintained, the world population of 7.2 billion in mid-2013 is projected to increase by almost one billion people within the next 12 years, reaching 8.1 billion in 2025, and to further increase to 9.6 billion in 2050, and 10.9 billion by 2100 (United Nations Department of Economic and Social Affairs 2013).

The fertility indicators in the MDGs are included in MDG 5A (Reduce by three quarters, between 1990 and 2015, the maternal mortality ratio)). This is the MDG on which least progress has been made. Although it is not possible to draw a causal link, it is quite plausible that the stubborn rate of decline in mater- 
nal mortality, particularly in countries with the highest fertility, has something to do with the politicisation of contraception that has affected the funding and delivery of contraceptive programmes over the last decade and a half. As well as being the slowest of the MDGs to improve, maternal mortality also shows the greatest disparity between rich and poor countries. It is no coincidence that sub-Saharan Africa has by far the highest maternal mortality ratio of any region (currently 500 out of 100,000 live births compared to 240 out of 100,000 for all developing country regions together), and also has the highest levels of unmet need for family planning (25 per cent compared to 13 per cent for all developing country regions) (United Nations 2013). Not surprisingly, maternal mortality in Africa tends to be lower in countries where levels of contraceptive use and skilled attendance at birth are relatively high. Indeed, the contribution of contraception to maternal mortality reduction globally is large. Estimates from 2008 show that the use of modern methods of contraception in developing countries was responsible for averting 230,000 maternal deaths, equivalent to a 43 per cent reduction, and much larger numbers of abortions and miscarriages were also averted (Singh et al. 2009).

Globally the education of girls, women's employment, and greater gender equity have influenced contraceptive uptake and desire for smaller family sizes among both women and men. The availability of new technologies through exposure to global debate on issues such as fertility and gender empowerment have also had an impact on increasing demand for and use of contraception. The 2013 MDGs Report shows that the use of mobile phones and the internet has increased very significantly during the 2000s, but we know nothing about the gendered make-up of this. By 2015, total demand for family planning among married women is projected to grow to more than 900 million, mostly due to population growth (United Nations 2013). Yet donor funding for family planning has occupied an ever decreasing proportion of population assistance. In 1999, family planning accounted for 37 per cent of the total global donor expenditure on population activities, while HIV/AIDS received 23 per cent. By 2009, HIV/AIDS received 68 per cent of the total population expenditure (despite declining since 2007), while family planning received only seven per cent (UNFPA 2011).

\section{What is the current debate about future goal setting?}

Today, population and family planning appear to be coming back onto donors' agendas, though still largely in relation to health. The 2012 London Summit on Family Planning and its associated spin-off activities has created probably the most influential donor forum for family planning-related global goal setting. The WHO's universal health coverage call has dominated its own global goalsetting negotiations, and UNFPA continues to track the standard demographic targets collected by the Demographic and Health Surveys Program around the 
world, as well as donor funding for population assistance, but has not strongly lobbied for their inclusion in the post-2015 goals and targets.

The SRHR civil society community that was so influential at the ICPD in Cairo is also re-engaging with the international post-2015 goal-setting negotiations to secure a target of universal access to SRH in the SDGs presented. Although they may be more engaged than other specific health communities, the voices of SRHR advocates are more fragmented than they were at the Cario ICPD (partly reflecting the continuing lack of consensus over the primacy of population issues versus the wide range of other SRHR goals arising from Cairo).

During the months before the 2009 United Nations Climate Change Conference in Copenhagen, the Population and Climate Change Alliance (a loose grouping of northern and southern NGOs working to increase awareness of the links between population dynamics and climate change) was formed to interact with the climate change and wider sustainable development discourse, building on new research on the linkages between population dynamics and climate change (Bryant et al. 2009). This network, now named the Population and Sustainable Development Alliance (PSDA), has been critical in securing small steps to reconnect population issues with sustainable development, including lobbying at the Rio+20 Summit negotiations and securing language on sexual and reproductive health, as well as a Health and Population section in the outcome document which notes 'Through forward looking planning, we can seize the opportunities and address the challenges associated with demographic change.' (UN General Assembly Resolution 66/288: para 144:28)). PSDA are also monitoring subsequent commitments. Most notably, perhaps, health and population dynamics were included on the agenda of the Fourth Session of the Open Working Group on Sustainable Development Goals meeting in 2013, and population dynamics was the theme of one of the 11 post-2015 United Nations thematic consultations and in April 2015 the UN Commission on Population and Development's 48th Session debated “integrating population issues into sustainable development, including in the post-2015 development agenda" (UN Commission on Population and Development 2015).

\section{References}

All Parliamentary Group on Population, Development and Reproductive Health. (2007, January). Return of the Population Growth Factor: Its impact upon the Millennium Development Goals (Report of Hearings by the All Party Parliamentary Group on Population, Development and Reproductive Health). London: House of Commons.

Bernstein, S. (2005). The changing discourse on population and development: toward a new political demography. Studies in Family Planning, 36(2), 127-132. 
Blanc, A. K., \& Tsui, A. O. (2005). The dilemma of past successes: insiders' views on the future of the International Family Planning Movement. Studies in Family Planning, 36(4), 263-276.

Bloom, D. E., Canning, D., \& Malaney, P. N. (2000). Population dynamics and economic growth in Asia. Population and Development Review, 26, Supplement: Population and Economic Change in East Asia (2000), 257-290.

Bongaarts, J. (2008). Fertility transitions in developing countries: progress or stagnation? Studies in Family Planning, 39(2), 105-110.

Bryant, L., Carver, L., Butler, C. D., \& Anage, A. (2009). Climate change and family planning: least-developed countries define the agenda. Bull World Health Organ, 87, 852-857.

Bryce, J., Black, R. E., Walker, N., Bhutta, Z. A., Lawn, J. E., \& Steketee, R. W. (2005). Can the world afford to save the lives of 6 million children each year? Lancet, 365, 2193-2200.

Coale, A. J., \& Hoover, E. M. (1958). Population growth and economic development in low-income countries. Princeton: Princeton University Press.

Crossette, B. (2005). Reproductive health and the Millennium Development Goals: the missing link. Studies in Family Planning, 36(1), 71-79.

Dixon-Mueller, R. (1993). Population policy and women's rights: transforming reproductive choice. Westport, USA: Praeger Publishers.

Eastwood, R., \& Lipton, M. (1999). The impact of changes in human fertility on poverty. Journal of Development Studies, 36 (1), 1-30.

Ehrlich, P. (1968). The population bomb. New York: Buccaneer Books.

Ezeh, A. C., Mberu, B. U., \& Emima, J. O. (2009). Stall in fertility decline in eastern African countries: regional analysis of patterns, determinants and implications. Philosophical Transactions of the Royal Society B, 364 (1532).

Mammen, K., \& Paxson, C. (2000). Women's work and economic development. Journal of Economic Perspectives, 14(4), 141-164.

Mayhew, S. H., \& Adjei, S. (2004). Sexual and reproductive health: challenges for priority-setting in Ghana's health reforms. Health Policy and Planning, 19, i50-i61.

Meadows, D. H., Meadows, D. L, Randers, J., \& Behrens III, W. W. (1972). The limits to growth. New York: Mentor and Plume Books.

Newman K., Fisher S., Mayhew S., Stephenson J. (2014) Population, sexual and reproductive health, rights and sustainable development: forging a common agenda. Reproductive Health Matters 22(43):53-64. DOI: http://dx.doi. org/10.1016/S0968-8080(14)43770-4

Sen, G., Germain, A., \& Chen, L. C. (Eds.) (1994). Population policies reconsidered: health, empowerment and rights. Boston, Massachusetts: Harvard Centre for Population and Development Studies.

Singh, S., Wulf, D., Hussain, R., Bankole, A., \& Sedgh, G. (2009). Abortion worldwide: a decade of uneven progress. New York: Guttmacher Institute.

United Nations. (2013). The Millennium Development Goals Report 2013. New York: United Nations. 
United Nations Commission on Population and Development (2015). Retrieved from http://www.un.org/en/development/desa/population/commission/ sessions/2015/index.shtml

United Nations, Department of Economic and Social Affairs. (2013). World population prospects: the 2012 revision, key findings and advance tables. Working Paper No. ESA/P/WP.227. New York: United Nations.

United Nations Millennium Project. (2006). Public choices, private decisions: sexual and reproductive health and the millennium development goals. Geneva, Switzerland: United Nations.

United Nations Population Fund (UNFPA). (2011). Financial resource flows for population activities in 2009. New York: UNFPA.

United Nations Population Fund (UNFPA). (2013). The demography of adaptation to climate change. London: UNFPA and International Institute for Environment and Development. 